\title{
Linking habitat and life history for conservation of the rare saltmarsh topminnow Fundulus jenkinsi: morphometrics, reproduction, and trophic ecology
}

\author{
John D. Lopez ${ }^{1,3}$, Mark S. Peterson ${ }^{1, *}$, Erik T. Lang ${ }^{1}$, Adriana M. Charbonnet $^{2}$ \\ ${ }^{1}$ Department of Coastal Sciences, The University of Southern Mississippi, Ocean Springs, Mississippi 39564, USA \\ ${ }^{2}$ Ocean Springs High School, Ocean Springs, Mississippi 39564, USA \\ ${ }^{3}$ Present address: Texas Parks and Wildlife, Coastal Fisheries Division, Brownsville Field Office, Brownsville, \\ Texas 78520, USA
}

\begin{abstract}
Fundulus jenkinsi is a state and federally listed Species of Concern because it is rare and is threatened by human activities, and ecological information is lacking. Fish collected from Louisiana, Mississippi, Alabama, and Florida, USA, during winter, spring, and summer were evaluated for selected habitat-linked reproductive and trophic metrics. Mouth-gape-weight relationships increased with standard length (SL) but did not differ by gender. An exposed genital papilla, an anal sheath, and an elongated posterior anal ray separated mature males from females in $86.7 \%$ of the fish examined (year round), and adding vertical bars and dark dorsal pigmentation increased this percentage to $96.7 \%$ (seasonal). There was a clear season-size spawning relationship, whereby fish $<20 \mathrm{~mm}$ SL were immature, and ovary phases and oocyte stages suggested that spawning initiated in spring/early summer. Diet did not vary by size-class but did vary seasonally. Summer diets were most similar to each other compared to other seasons, with prey consisting of arachnids, crab zoea, dipterans, amphipods, hymenopterans, and hemipterans. Aquatic prey size classes shifted with increased fish size and mouth gape, which allowed for larger prey to be consumed. Smaller-bodied terrestrial prey were consistently consumed regardless of fish body size. Overall, reproduction and diet are strongly linked with mid- and high salt marsh access. These data highlight small, interconnected intertidal creeks embedded within salt marshes as access points for reproduction and foraging and suggest that 'dendritic' complexes of intertidal creeks should be a focus in conservation planning efforts, and that efforts to restore tidal marsh habitat should attempt to mimic these naturally occurring complexes.
\end{abstract}

KEY WORDS: Fundulidae $\cdot$ Connectivity $\cdot$ Foraging $\cdot$ Insects $\cdot$ Mid-marsh $\cdot$ High marsh $\cdot$ Salt marsh Resale or republication not permitted without written consent of the publisher

\section{INTRODUCTION}

In estuaries of the Atlantic coast and the Gulf of Mexico (GOM), Fundulus species are abundant residents of shallow-water environments (Nordlie 2006) and are prey for a wide variety of resident and transient nekton (Kneib 1997). Species like mummichog F. heteroclitus and gulf killifish F. grandis are well-studied (Kneib 1986, 2000), but little or no ecological or life history information is available for species such as spotfin killifish F. luciae, bayou killifish F. pulvereus, marsh killifish F. confluen- tus, and saltmarsh topminnow F. jenkinsi. There appear to be 2 sets of geminate Fundulus species (species with similar body size and ecological requirements): F. grandis - F. pulvereus - F. jenkinsi in the northern GOM, and $F$. heteroclitus $-F$. confluentus $-F$. luciae on the east coast (Lopez et al. 2010). However, Relyea (1965), Foster (1967), and Hardy (1980a,b) noted that F. confluentus and $F$. pulvereus are probably not distinct species, and $F$. confluentus has been collected on the west coast of Florida and in Alabama (Reid 1954, Kilby 1955, Swingle \& Bland 1974, Lopez et al. 2010). 
Fundulus jenkinsi is listed by the National Marine Fisheries Service (NOAA 2009) and the states of Louisiana, Mississippi, Alabama, and Florida as a Species of Concern for coastal areas because it is rare and is threatened by human activities, and general biological and ecological information is lacking (Gilbert \& Relyea 1992, Thompson 1999, Peterson et al. 2003, NOAA 2009). Thus, there is a need for a comprehensive conservation plan for this species and its habitat (Peterson \& Lopez 2008), but we currently lack knowledge of its reproductive life history and trophic ecology, which are essential elements in effective and informed management and conservation. Recently, habitat characteristics of $F$. jenkinsi were quantified and showed that this species occurred mainly within shallow water of low to moderate salinity $(77.4 \%$ $<16$ ppt) saltmarsh environments (Lopez et al. 2010).

The basic life history of many fundulids is similar. For instance, most fundulids have a reproductive season from late February through August (Greeley \& MacGregor 1983, Greeley 1984, Greeley et al. 1986), and Byrne (1978) and Kneib (1978) showed that the spawning season of Fundulus luciae occurs from midMarch until mid-September, as indicated by the presence of mature and maturing oocytes in the ovary. As semi-lunar batch spawners, use of tides to reach the marsh surface spawning sites is necessary (Harrington \& Haeger 1958, Harrington \& Harrington 1972, Byrne 1978).

Sexual dimorphism is common in fundulids (Newman 1907, 1909, Fowler 1916, Byrne 1978, Thompson 1999), but has rarely been quantified for many fundulid species. Moreover, some characters change with age, season, and location, making external gender determination problematic. For example, Fowler (1916) noted that mature male striped killifish Fundulus majalis often have an enlarged anal fin, and this enlargement has been observed in mature male $F$. jenkinsi along with a small exposed genital papilla (Thompson 1999). During the spawning season, some mature male $F$. jenkinsi possess lemon-yellow anal fin coloration (Thompson 1980, 1999), and mature $F$. luciae (Byrne 1978) possess pigmented vertical bars. Furthermore, some mature male F. pulvereus have intermittent lateral dark spots that can form longitudinal stripes (Boschung \& Mayden 2004), which has also been documented in some F. majalis (Newman 1909). Female fundulids, on the other hand, exhibit an anal tube or sheath along the anterior of the first few anal rays (Fowler 1916), which is thought to be used to position eggs during spawning (Thompson 1999). Dimorphic characters of females are generally expressed by the absence of fin coloration (Byrne 1978, Thompson 1999), or in some fundulids, a posterior dorsal fin ocellus (F. luciae; Byrne 1978; F. pulvereus, Boschung \&
Mayden 2004). Mature F. confluentus possess both the posterior ocellus and spots on their dorsal fin during the breeding season (Granier 1998). Unfortunately, pigmentation-based characters are only useful during the spawning season in freshly captured or recently preserved specimens, whereas morphological characters are useful once individuals reach maturity. In fact, many standard texts (Ross 2001, Boschung \& Mayden 2004) discuss sexually dimorphic characters in fundulids, but there are no carefully illustrated images of morphometric characters (female anal sheath, male genital papilla and elongated anal fin ray) that would aid in external gender determination, which is particularly important in rare species.

Foraging by resident species like fundulids links various salt marsh habitats across the landscape, from terrestrial to subtidal (Kneib 1997, 2000). For example, Fundulus luciae is a small-bodied fundulid that forages primarily at the high marsh surface (Byrne 1978, Kneib 1978) on detritus, diatoms, ostracods, insects (hemipterans and dipterans), copepods, and amphipods, with clear seasonal variation in consumption based on prey availability (Byrne 1978, Kneib 1978). The diet of another mid- and high marsh fish, F. confluentus, consisted primarily of crustaceans $(21 \%)$, insects such as mosquitoes (Aedes spp.; 18 to $24 \%$ ), and a combination of neonate mosquitofish Gambusia affinis and juvenile sailfin molly Poecilia latipinna (36\%) (Harrington \& Harrington 1961, 1972). In total, these findings suggest that killifish are opportunistic feeders that use the mid- and high marsh habitat (Harrington \& Harrington 1961, Odum \& Heald 1972, Weisberg et al. 1981) and transfer energy (aquatic and terrestrial) from the high marsh surface through intertidal creeks to the subtidal estuary (Rozas \& LaSalle 1990, Kneib 1997, Lefeuvre et al. 1999, Rountree \& Able 2007). This pattern can vary by species, body and gape size, season, and geographic location, which may change the available prey spectrum, but this variation is a defining characteristic of transition systems (Schiemer et al. 1995) such as estuaries.

More research on reproduction details and feeding habits of resident and transient nekton is required to elucidate the importance of estuarine habitat (Roundtree \& Able 2007). Given the lack of biological data on Fundulus jenkinsi, its rarity, and the fact that salt marsh habitat is being hardened (e.g. by installation of bulk heads and rip-rap) worldwide (Jordan et al. 2008, Peterson \& Lowe 2009), accurate data on habitat-linked reproduction and feeding ecology of this rare Species of Concern are warranted. Thus, the specific objectives of this study were to (1) quantify body morphometrics by gender; (2) quantify which pigmented and morphological sexually dimorphic characters are useful to characterize male and female individ- 
uals accurately; (3) illustrate these morphological characters; (4) examine the distribution of ovarian phases and oocyte stages by size class and season; (5) quantify the diet of $F$. jenkinsi relative to ontogeny; and (6) determine ontogenetic changes in the mouth gape and prey width relationship. These newly documented data will be used to link life history and habitat use for development of conservation strategies.

\section{MATERIALS AND METHODS}

Fish collections and measurements. Fundulus jenkinsi were collected from estuaries in Louisiana, Mississippi, Alabama, and Florida, USA, (see Lopez et al. 2010 for details) using Breder traps (Breder 1960). Breder traps were made of clear $6.4 \mathrm{~mm}$ plexiglass boxes $(30 \times 15 \times 15 \mathrm{~cm})$ with 2 wings $(30 \times 15 \mathrm{~cm})$ forming a $12 \mathrm{~mm}$ entry slot that faced towards the marsh surface at high tide and captured fish leaving the marsh at low tide. Trapping was conducted in pure Spartina alterniflora marsh edge, S. alterniflora marsh edge that bordered Juncus roemerianus marsh, and pure J. roemerianus marsh edge. Within basins of the 4 regions, 30 traps were deployed daily for 3 consecutive days (90 total traps) 6 times in 2007 to 2008 during winter (February to early March), spring (midMarch to end of April), and summer (late May to early September). The majority of fishes were collected at mid-marsh edges (irregularly flooded saline marsh, Wieland 2007) associated with small tidal creeks adjacent to high marsh (saltmeadow cordgrass herbaceous coastlands, Wieland 2007). However, some were also collected at low marsh edges (frequently flooded saline marsh, Wieland 2007). Wet specimens were blotted and weighed (WW, nearest mg), measured for standard (SL), and total (TL) length (mm), and placed into $5 \mathrm{~mm}$ SL size classes $(\mathrm{n}=10)$. A maximum of 10 individual fish were randomly selected from each season, location, and size-class grouping for subsequent analysis using a random number table when $n>10$ per category. Length-weight and length-gape relationships were examined by gender because fundulids generally exhibit sexual dimorphism (Ross 2001, Boschung \& Mayden 2004). If there were no differences by gender, samples were pooled. Data used for the reproductive portions of this paper were obtained within 6 to 7 mo after preservation from 2008 specimens only.

Morphometrics. Morphometric measurements were taken on 349 Fundulus jenkinsi ranging from 6.06 to $55.32 \mathrm{~mm}$ SL. Mouth gape was measured using a digital caliper as the distance between the outer maxillary bone edges directly beneath the eyes, which has been found to be a good estimate of the distance between the cleithrum bones (Lawrence 1958). This measurement represents the throat diameter and is a critical limiting factor associated with prey consumption (Peterson \& VanderKooy 1996, Timmerman et al. 2000). Maximum prey body width was estimated, based on the top 3 most abundant prey consumed (mean of the 3 largest prey individuals consumed per taxon) with an ocular micrometer. These measurements were used to quantify the relationship between fish SL, mouth gape (mm), and prey width (mm).

Dimorphic characters. External gender determination followed Thompson (1999), Ross (2001), and Boschung \& Mayden (2004). Although the pigmented characters have been clearly described, the key morphological characters have been neither illustrated nor quantitatively analyzed. Pigmented characters examined included vertical bars, faint longitudinal stripes on the body, dorsal fin pigmentation, and lemon-yellow anal fin coloration. Morphological characters examined included the presence or absence of an anal sheath, a small exposed genital papilla, and length of the posterior anal fin ray from the most anterior insertion point to the ray tip as a proportion of fish TL on fish ranging from 6.06 to $55.32 \mathrm{~mm}$ SL. All 2008 fish ( $\mathrm{n}=$ 167) were examined by 2 individuals who independently determined gender using the characters listed above. When gender determination differed between observers, fish were re-examined. When consensus was not reached, the fish were removed from analysis, resulting in a final sample size of 158. Finally, sexual determination was confirmed by removing the gonads and examining them macroscopically.

Reproduction methodology. To classify ovarian phase and oocyte stage distributions, ovaries were examined from 167 females (size range $=10.03$ to $55.32 \mathrm{~mm}$ SL) collected in 2008. Classifications were based on a northern starhead topminnow Fundulus dispar scheme (Taylor \& Burr 1997), but the terminology was modified for ovary phases following BrownPeterson et al. (2007) and for oocyte stages following Grier et al. (2009; Table 1). All oocyte diameters (mm) were estimated from histologically prepared fish (E. Lang unpubl. data).

Illustrations. Sexually dimorphic characters were initially photographed at various focal points with a Jenopik C5 digital camera attached to a Meji dissecting scope. All images were imported into Adobe Photoshop CS3 to achieve a uniformly focused picture by overlaying images of various opacities. Genital papilla, the anal sheath, and the anal fin rays were traced on a $9 \times 12$ Wacom Intuos drawing tablet with Adobe Photoshop CS3. Specimens used to draw the dimorphic characters were catalogued into the Gulf Coast Research Laboratory (GCRL) Ichthyology Museum (GCRL 36 380, 36 382, 36384, 36 386). 
Table 1. Fundulus jenkinsi. Descriptions for classifying (a) reproductive phases of ovaries and (b) oocyte stages, originally developed for F. dispar (Taylor \& Burr 1997), with modified terminology by Brown-Peterson et al. (2007) and Grier et al. (2009).

Diameters based on histologically prepared fish

\begin{tabular}{|c|c|c|}
\hline $\begin{array}{l}\text { a) Ovary phases } \\
\text { Taylor \& Burr (1997) }\end{array}$ & Brown-Peterson et al. (2007) & Modified for F. jenkinsi (present study) \\
\hline Latent & Immature or regenerating & Very small, white, all oocytes $<0.5 \mathrm{~mm}$ \\
\hline Early maturing & Early developing & Small to moderate, white, oocytes $\geq 0.7 \mathrm{~mm}$ \\
\hline Late maturing & Late developing & Small to large, mostly white with yellow, oocytes $\leq 1.0 \mathrm{~mm}$ \\
\hline Mature & Spawning capable & Large, distending abdomen, yellow, oocytes $<1.3 \mathrm{~mm}$ \\
\hline Ripe & Actively spawning & Large, a batch of oocytes $<1.3 \mathrm{~mm}$ \\
\hline \multicolumn{3}{|l|}{ b) Oocyte stages } \\
\hline Taylor \& Burr (1997) & Grier et al. (2009) & Modified for F. jenkinsi (present study) \\
\hline Immature & $\begin{array}{l}\text { Cortical alveolar and early } \\
\text { secondary growth }\end{array}$ & Opaque and white, diameter: $0.25-0.70 \mathrm{~mm}$ \\
\hline Mature & Late secondary growth & Opaque and yellow, diameter: $0.7-1.0 \mathrm{~mm}$ \\
\hline Ripening & Full grown & Transparent and light yellow, diameter: $1.0-1.3 \mathrm{~mm}$ \\
\hline Ripe & Oocyte maturation & Transparent and light yellow, diameter: >1.3 mm \\
\hline
\end{tabular}

Trophic ecology. Stomach contents of preserved fish (see details in Lopez et al. 2010) ranging from 6.06 to $55.32 \mathrm{~mm}$ SL $(\mathrm{n}=350)$ were taken from the first turn of the intestine, defined as the area between the esophagus and the posterior opening of the stomach (Babkin \& Bowie 1928), and were identified to the lowest possible taxonomic level following Heard (1982), Abele \& Kim (1986), Merritt \& Cummins (1996), and Heard et al. (2006). Frequency of occurrence $(\mathrm{Fo})$ and prey percent volume (v) were estimated for each Fundulus jenkinsi. We used a squash plate technique with plates constructed of microscope slides and stacks of coverslips (Rakocinski \& Zapfe 2005) to estimate prey volume. Seven to 9 different volumes of $\mathrm{KOH}$-glycerol with 3 replicates per volume were used to develop a standard area-volume curve (Rakocinski \& Zapfe 2005). Individual prey items were uniformly squashed and the area of the squash determined using a Nikon ${ }^{\circledR}$ image analysis system consisting of a DMX 1200 digital camera attached to an SMZ 1500 stereomicroscope. MetaVue ${ }^{\circledR} 5.0$ imaging software was used to estimate volume from images captured from squashes, where the prey were traced 3 times to obtain a mean area $\left(\mathrm{mm}^{2}\right)$. The volume of each prey type $(\mu \mathrm{l})$ was estimated from a measured area of the squashed prey using a squash plate of known depth (Hyslop 1980). Two calibration curve regressions with a 0 intercept were developed for prey volume estimates ranging from 3.0 to $14.5 \mu \mathrm{l}$ and 10.5 to $30.0 \mu \mathrm{l}$, and volumes were estimated from these 2 curves. These relationships were expressed as volume $(\mu \mathrm{l})=a\left(\right.$ area $\left.\left[\mathrm{mm}^{2}\right]\right)$, where $a=$ the slope of the relationship. For small-volume prey, the equation was volume $=0.3159$ (area) $\left(r^{2}=0.9918\right)$, whereas for the large-volume prey, the equation was volume = 0.6386 (area) $\left(\mathrm{r}^{2}=0.9930\right)$. For prey larger than the second calibration curve, volume was estimated from weight $(\mathrm{g})$ measured on an Ohaus ${ }^{\circledR}$ Analytical Plus microbalance using the conversion factor of $1.13 \mathrm{~g}$ $\mathrm{cm}^{-3}$ (Rakocinski \& Zapfe 2005).

Data analysis. Analysis of covariance (ANCOVA; Field 2005) was used to compare male and female slopes and $y$-intercepts for the following relationships: SL-WW (with SL as the covariate); SL-mouth gape on all fish (with SL as the covariate); and SL-mouth gape on a subset of fish related to diets (with SL as the covariate). If the homogeneity of slopes assumption was met, the $y$-intercepts were compared; however, if the relationships were not homogeneous, then separate linear regression equations were presented and interpreted. Finally, if there was no difference in $y$ intercepts among gender, we pooled the gender data and conducted a linear regression on SL-WW or SL-mouth gape. Prior to any of these analyses, each variable was tested for the homogeneity of variance (Levene's test), normality (Kolmogorov-Smirnov 1sample test), homogeneity of slopes assumption of ANCOVA, and plotted standardized residuals for the regressions; if assumptions were not met, the variables were $\log _{10}$ transformed prior to analysis. The linear relationship between SL and mouth gape was plotted based on the subset of Fundulus jenkinsi noted below (Table 2) (only fish with volumetrically common prey taxa; $\mathrm{n}=229$ ) and common prey taxa noted in the diet. A $20 \%$ compression line was added to the plot, as Peterson \& VanderKooy (1996) suggested that measured body width should be larger by about $20 \%$ in relation to the compression of prey during feeding. 
All parametric statistical analyses were conducted using SPSS 15.0, and significance was determined when $\mathrm{p} \leq 0.05$ (Field 2005).

Initially, we conducted a 2-way nested analysis of similarities (ANOSIM; Clarke 1993) to test for differences in fourth-root transformed mean prey volume and frequency of occurrence of the diet data with size class $(n=6$; all individual fish were pooled into 2 replicates for each size class in each season in order to conduct the analysis) nested within season $(\mathrm{n}=3)$. We reduced the number of size classes and individuals ( $\mathrm{n}=$ 247 total fish) examined in order to obtain an equal representation of size classes within each season. Subsequently, R-statistic (values close to 1 suggest diets are very different, whereas values close to 0 suggest they are very similar) and p values were used in interpretation prior to any further analyses. Based on the output of these analyses, we determined that both results were almost identical and that size class was not statistically important, so only prey volume coupled with season was considered in further analyses. The R-statistic and $\mathrm{p}$ values were used in a pairwise manner to compare mean prey volume among seasons.

Cluster analysis based on the hierarchical agglomerative method with the group-average linkage and nonmetric multi-dimensional scaling (MDS) procedures were used to compare fourth-root transformed mean prey volume of pooled individuals seasonally with the Bray-Curtis similarity coefficient. Both analyses were computed using PRIMER (version 6.1.6; PRIMER-E, Clarke \& Gorley 2006); these values range from 0 to $100 \%$, with $0 \%$ indicating no similarity and $100 \%$ being identical (Clarke 1993). Both analyses attempt to create groupings of samples (season/replicate combination, $\mathrm{n}=36$ ) based on the variables (prey taxa, $\mathrm{n}=$ 39) through a generated similarity matrix. If MDS stress values were between 0.15 and 0.20 (Clarke \& Gorley 2006), we superimposed groups from the cluster analysis at a $45 \%$ similarity level onto the ordination to search for adequacy and mutual consistency between techniques. To highlight important mean prey volume seasonally, we used the 2D bubble option within the MDS ordination plots. Multivariate disper- sion (MVDISP) was used to delineate variability in the diet components among seasons (high values equal more dispersion of the diet), while the similarity percentages (SIMPER) analysis was used to disaggregate the similarity matrix to identify which diet components were most responsible for any dissimilarity between seasons (Clarke 1993, Clarke \& Gorley 2006).

For the pigmented and morphological characters, we quantified percent correct identification based on 2 blind evaluations. We conducted Student's $t$-test on the posterior anal ray length expressed as a percentage of TL to compare males and females. We also conducted a backward removal likelihood ratio (Backward LR) logistic regression (Field 2005) with gender (male/ female) as the dependent variable and the presence/ absence of the genital papilla (male) and the anal sheath (female), and the posterior anal ray length (mm) expressed as a percent of fish TL as the continuous variable. After the measurements were completed on an individual, definitive gender was determined by examination of the gonads, and only clearly identified male and female fish were used in the analysis. Finally, percent distribution of the ovary phase and oocyte stage were plotted across season and SL size class to determine season- and size-dependent shifts from juvenile to adult fish.

\section{RESULTS}

\section{Morphometrics}

In an ANCOVA comparison of SL and mouth gape relationships between male and female Fundulus jenkinsi (with SL as the covariate), the homogeneity of slopes assumption was met $\left(F_{1,319}=0.116, \mathrm{p}=0.734\right)$, but there was no gender difference in mouth gape adjusted for SL $\left(F_{1,319}=0.017, \mathrm{p}=0.676\right)$. Thus, we pooled male, female, and unknown gender fish and found a significant relationship between SL and mouth gape for the complete array of fish and for the subset of fish used to examine the SL-mouth gape-mean prey width relationship (Table 2).

Table 2. Fundulus jenkinsi. Regression equations and relevant statistics for comparisons conducted on body morphometrics as separate genders or pooled. SL: standard length (mm), WW: wet weight (mg), gape: mouth gape (mm), N: no. of fish

\begin{tabular}{|c|c|c|c|c|c|}
\hline Comparison & Equation & $\mathrm{r}^{2}$ & $F$ & $\mathrm{p}$ & $\mathrm{N}$ \\
\hline SL-gape ${ }^{a}$ & Gape $=(0.109 \times \mathrm{SL})-0.257$ & 0.944 & 5900.42 & $<0.001$ & 349 \\
\hline SL-gape ${ }^{b}$ & Gape $=(0.108 \times \mathrm{SL})-0.238$ & 0.940 & 3532.93 & $<0.001$ & 229 \\
\hline $\log _{10} \mathrm{SL}-\log _{10} \mathrm{WW}$ (pooled) & $\log _{10} W W=\left(3.090 \times \log _{10} S L\right)-1.891$ & 0.976 & 26127.21 & $<0.001$ & 650 \\
\hline
\end{tabular}


An ANCOVA (with $\log _{10}$ SL as the covariate) showed that the $\log _{10}$ SL versus $\log _{10}$ WW relationships between male and female Fundulus jenkinsi were homogeneous $\left(F_{1,559}=1.340, \mathrm{p}=0.248\right)$ and the $\log _{10}$ SL-adjusted $\log _{10} \mathrm{WW}$ was not different between genders $\left(F_{1,559}=0.771, \mathrm{p}=0.380\right)$. This relationship indicates that WW increases equally with increasing SL regardless of gender, as indicated by the slope of the model (Table 2).

\section{Dimorphic characters}

The usefulness of sexually dimorphic morphological characters (Fig. 1A-D) used to separate male from female fish varied because pigmented characters varied seasonally (i.e. they were present from March through September). Observers examining only 3 pigmented characters for males during the spawning season (10 from mid-May, 6 from mid-June, and 26 from across August; $\mathrm{n}=42$ ) were able to identify them as males based on dorsal coloration $(71.4 \%)$ and vertical bars $(78.6 \%)$ more often than anal fin coloration $(7.1 \%)$, which is probably related to the date (season) when the fish were actually collected. The Backward LR logistic regression overall model was significant (-2 $\log$ likelihood $=111.696 ; \chi^{2}=15.877, \mathrm{p}=0.044$ ), and the Nagelkerke $\mathrm{R}^{2}$ was 0.647 , suggesting the data fit the model well. Of the 67 fish thought to be male, 49 $(73.1 \%)$ were male when examined internally. In contrast, $96.7 \%$ (88 of 93 examined) of the females were correctly classified. Overall, the weighted mean percentage classified (male or female) based on presence/absence of genital papilla (Fig. 1D) and anal ray
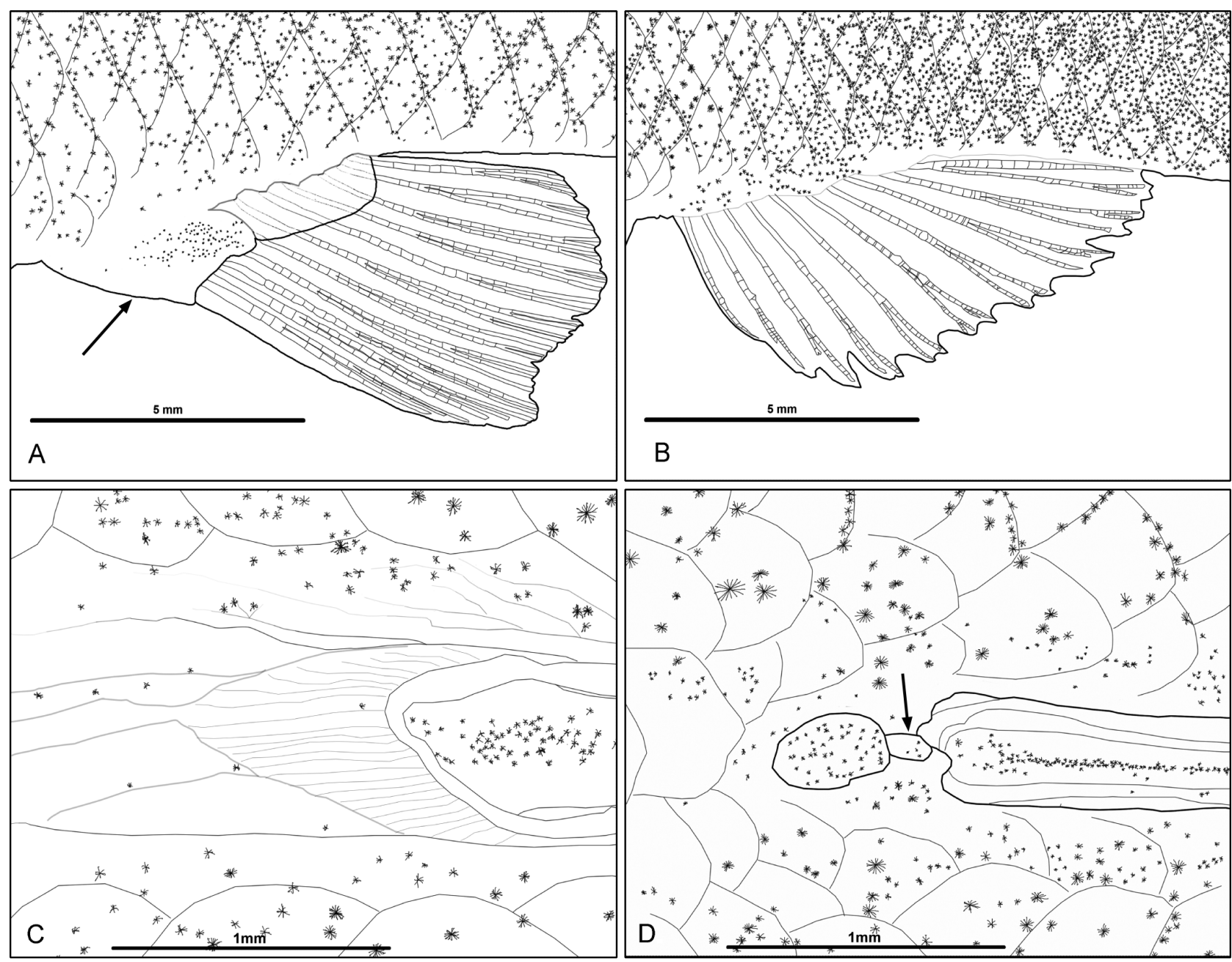

Fig. 1. Fundulus jenkinsi. (A) Female anal fin with sheath (46.7 mm total length, TL), (B) male anal fin (42.2 mm TL), (C) female genital region (57.1 mm TL), and (D) male genital region with small exposed papilla (45.6 mm TL). Illustrations in (A) and (B) are lateral views, whereas those in (C) and (D) and ventral views. Markings show relative sizes of pigments on fish collected from March to September. Arrows in (A) and (D) point to the anal sheath and exposed genital papilla, respectively 
length (Fig. 1B) as a percentage of TL alone was $86.7 \%$ correctly classified, and genital papilla ( $\mathrm{p}<$ $0.001)$ and posterior anal ray length $(p=0.008)$ in the model were significant, suggesting that the presence of a genital papilla and a long posterior anal ray distinguishes males from females. The anal sheath (Fig. 1A,C) character did not load significantly into the model ( $p=0.329)$, suggesting that absence is characteristic of males. The length of the anal fin ray as a percentage of TL was also significantly longer in males $($ mean \pm SE: $8.57 \pm 0.309)$ than females $(6.47 \pm 0.148$; Student's $t=6.136, \mathrm{df}=96.153, \mathrm{p}<0.001)$. There was a high percent success rate of correctly distinguishing males $(94.1 \%)$ from females $(96.7 \%)$ based on all sexually dimorphic characters combined. In general, once the fish reached maturity, the morphological characters were more suitable for identifying gender than the pigmented characters.

\section{Reproduction patterns}

Ovarian development showed a clear seasonal progression, with the highest percentage of fish in the early developing phase in winter. The percentage of fish in the late developing phase increased from winter to summer, whereas the percentage of spawningcapable fish was lowest in spring (Fig. 2A). Actively spawning fish were captured during spring and early summer. It was also clear that this relationship was size dependent, as fish $<20 \mathrm{~mm}$ SL were all in the immature phase, and the early developing phase started in fish $>20 \mathrm{~mm}$ SL (Fig. 2B). Oocyte development followed a similar seasonal and size-related pattern (Fig. 3). In winter, there were no full grown or late secondary growth oocytes in fish $<30 \mathrm{~mm}$ SL, but spring fish as small as $25 \mathrm{~mm}$ SL had late secondary growth oocytes, and some fish between 30 and $35 \mathrm{~mm}$ SL were undergoing oocyte maturation (Fig. 3). Finally in summer, fish as small as $20 \mathrm{~mm}$ SL had secondary growth oocytes (Fig. 3). Mature oocytes of Fundulus jenkinsi are $>1.3 \mathrm{~mm}$ diameter (E. Lang unpubl. data).

\section{Trophic ecology}

Diets of 247 Fundulus jenkinsi ranging from 15.02 to $44.94 \mathrm{~mm}$ SL (6 size classes in each season) were quantified. The number of fish used in the diet analysis varied seasonally in that $60.7 \%(n=150)$ were collected in summer, $19.8 \%(\mathrm{n}=49)$ in winter, and $19.4 \%$ ( $\mathrm{n}=48$ ) in spring. For those size classes included in the dietary analyses, details of the mean relative volumetric data of prey by season can be found in Tables S1 to
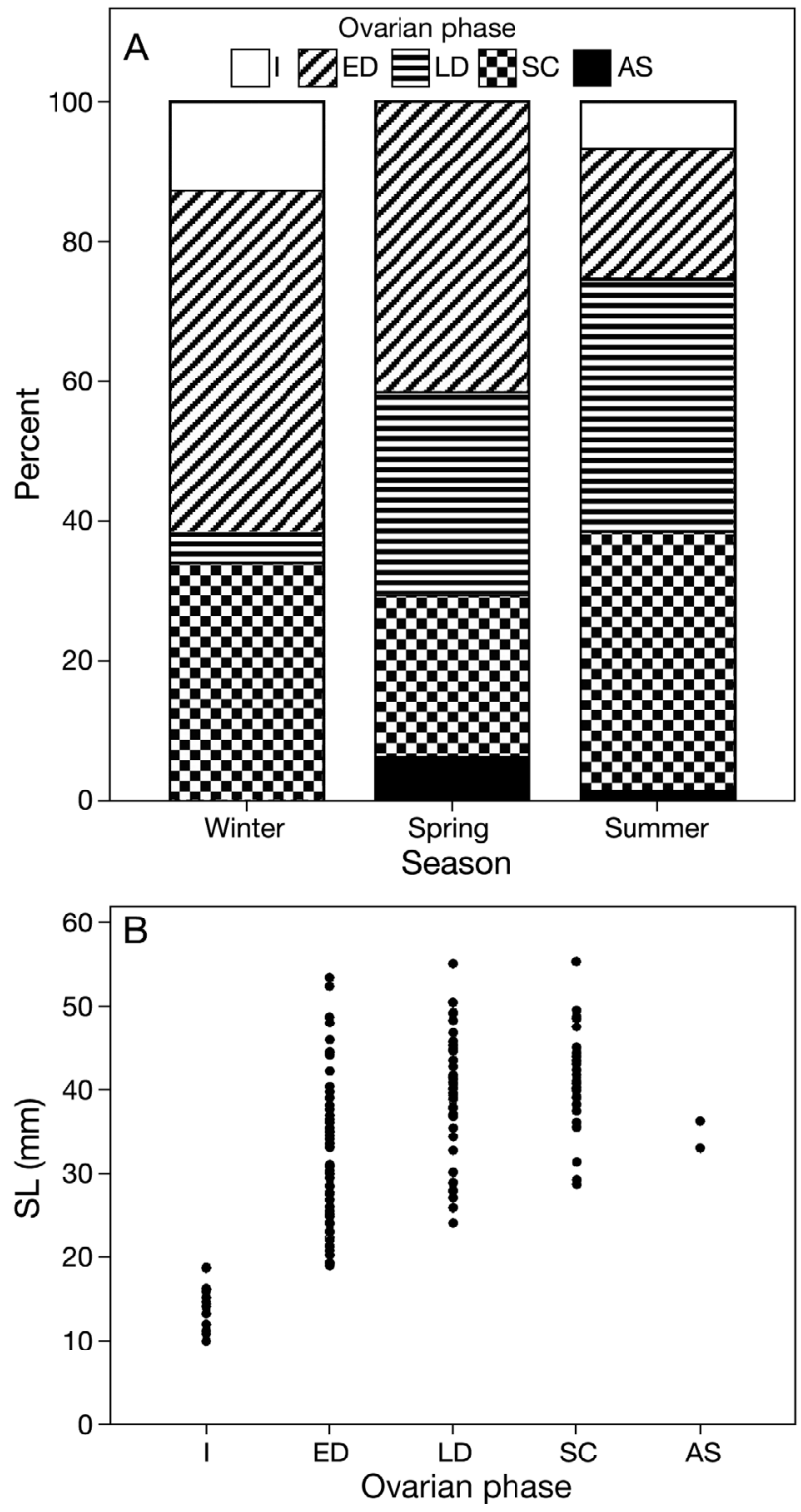

Fig. 2. Fundulus jenkinsi. (A) Seasonal percentages of ovarian phases of saltmarsh topminnow. I: immature, ED: early development, LD: late development, SC: spawning capable, and AS: actively spawning (Brown-Peterson et al. 2007). Sample sizes are winter $(n=35)$, spring $(n=30)$, and summer $(n=102)$.

(B) Ovarian phase distribution by standard length ( $\mathrm{SL}, \mathrm{mm})$

S3 in the supplement at www.int-res.com/articles/ suppl/n012p141_supp.pdf.

The results of the 2-way ANOSIM (size class nested within season) showed no size class effect on diet (global $\mathrm{R}=0.004, \mathrm{p}=0.499$ ), whereas diet was significantly different among seasons (global $\mathrm{R}=0.432, \mathrm{p}=$ 0.001). Pairwise tests among seasons showed that spring and summer diets differed significantly $(\mathrm{R}=$ $0.436, \mathrm{p}<0.001)$ as did summer and winter diets $(\mathrm{R}=$ 0.849, $\mathrm{p}=0.001$ ), but no diet difference was noted 


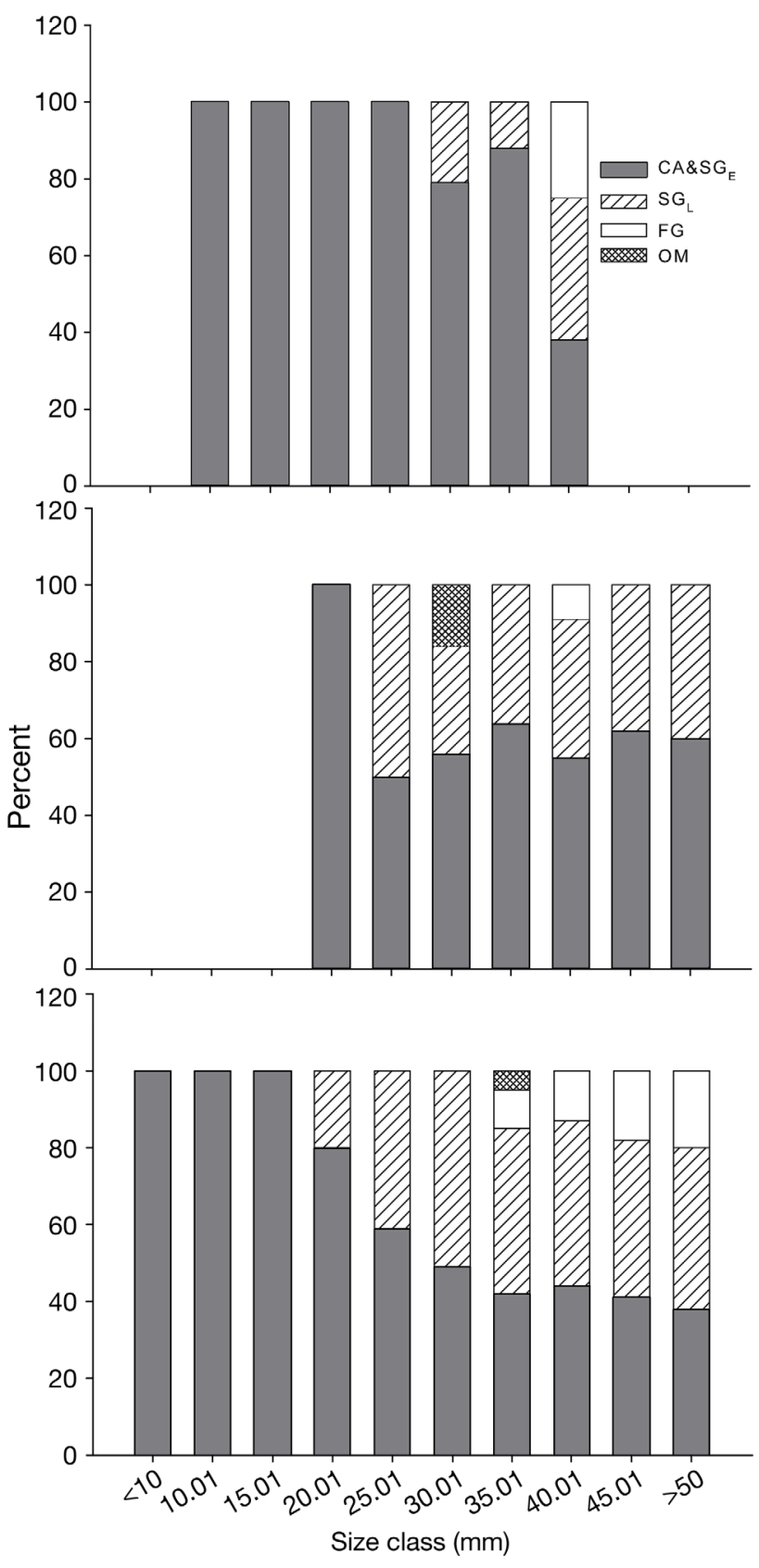

Fig. 3. Fundulus jenkinsi. Percentage of oocyte stage distribution by $5 \mathrm{~mm}$ size classes in (A) winter, (B) spring, and (C) summer. Size classes: $<10=$ all fish $<10 \mathrm{~mm}, 10.01=$ all fish $>10$ but $<15.01 \mathrm{~mm}$, etc. Number of individuals evaluated is shown at the top of each bar. CA: cortical alveolar, $\mathrm{SG}_{\mathrm{E}}$ : early secondary growth, $\mathrm{SG}_{\mathrm{L}}$ : late secondary growth, FG: full grown, OM: oocyte maturation (Grier et al. 2009)

between spring and winter $(\mathrm{R}=0.070, \mathrm{p}>0.05)$. Diets with greatest similarity (SIMPER values in decreasing order) were summer (56.21), winter (51.09), and spring (37.60). The breadth of the diet among seasons (MVDISP values) was lowest for summer (0.775) followed by winter (0.876) and spring (1.349). Finally, pairwise comparisons of seasons suggested that spring was more dissimilar and thus fish had more variable diets than in the other seasons (Table 3 ).

Fundulus jenkinsi foraged on both aquatic and terrestrial (mid- and high marsh) prey taxa. The main summer diet consisted of arthropod parts, Hemiptera (true bugs), crab zoea, Diptera (flies), amorphous debris, arachnids (spiders), and Hymenoptera (ants; Table 3 and Tables S1 to S3 in the supplement), and summer fish diets were most distinct (Fig. 4A) among the seasons (Table 3 , all pairwise $\mathrm{R} \geq 0.436$ ). Winter diets consisted mainly of amphipods, Diptera, arthropod parts, Hemiptera, and Collembola (springtails), many of which appeared to be high marsh/terrestrial in origin (Fig. 4B-H, Table 3). Spring diets were more variable (more widely distributed and mixed with winter and summer clusters in the MDS plots; Fig. 4B-H), and they consisted of dipterans, amphipods, arthropod parts, hemipterans, and amorphous debris.

Both aquatic and terrestrial ecological groups of prey were consumed by Fundulus jenkinsi (Figs. 4 \& 5). Additionally, within each group, some prey were consumed by many size classes of $F$. jenkinsi, whereas other prey were only consumed by small individuals (Table 4). For example, aquatic prey like amphipods and gastropods were found across many size classes of $F$. jenkinsi, and in both groups, large individuals were consumed by larger F. jenkinsi (Fig. 5A, Table 4); however, small gastropods were also found in fish $\leq 20 \mathrm{~mm}$ SL (Fig. 5A, Table 4). Crab zoea were consumed across a range of fish sizes, but these prey were much smaller than the mouth gape of F. jenkinsi, regardless of fish size (Fig. 5A); copepods were found exclusively in $F$. jenkinsi $<25 \mathrm{~mm}$ SL (Fig. 5A). A similar pattern in prey consumption was found for springtails (Collembola), flies (Diptera), true bugs (Hemiptera), and ants (Hymenoptera), except that small F. jenkinsi (<10 mm SL) did not consume these prey (Fig. 5B). Diptera, Hemiptera, and Hymenoptera were consumed across size classes of $F$. jenkinsi, with prey width increasing as fish size increased (Table 2). Collembola, like crab zoea, were consumed by F. jenkinsi between 13 and $41 \mathrm{~mm} \mathrm{SL}$, although prey width did not increase as much as other prey consumed with increased size of $F$. jenkinsi. These data suggest that many small-bodied prey are consumed, but large prey progressively dominate the diets of large F. jenkinsi. There appears to be a shift from copepod, small gastropods, and small terrestrial taxa in fish up to $\sim 25 \mathrm{~mm} \mathrm{SL}$, with large fish consuming crab zoea, amphipods, and all terrestrial prey taxa (Fig. 5A,B, Table 4). Overall, 87.9\% of prey consumed were on or below the regression line, $5.3 \%$ fell between the $20 \%$ compression line and the regression, and only $6.8 \%$ of prey had widths above the $20 \%$ compression line (Fig. 5A,B), suggesting that $F$. jenkinsi is a gape-limited forager. 
Table 3. Grand mean pairwise volume ( $\mu \mathrm{l}$ ) of important prey taxa of Fundulus jenkinsi by season based on similarity percentages analysis (SIMPER). Prey taxa are listed in order of their contribution to the grand mean dissimilarity (diss.) between pairs of seasons (column 5), with a cutoff when cumulative percent contribution to grand mean dissimilarity approaches about $70 \%$. Sp: spring, Su: summer, W: winter

\begin{tabular}{|c|c|c|c|c|c|c|}
\hline \multirow[t]{2}{*}{ Prey items } & \multirow{2}{*}{$\begin{array}{c}\text { Pairs } \\
\text { Sp vs. Su }\end{array}$} & \multicolumn{2}{|c|}{ Grand mean volume $(\mu \mathrm{l})$} & \multirow{2}{*}{$\begin{array}{c}\text { Grand mean diss. } \\
60.12(\%)\end{array}$} & \multirow[t]{2}{*}{ Grand mean diss./SD } & \multirow[t]{2}{*}{ Contribution (\%) } \\
\hline & & Spring & Summer & & & \\
\hline Crab zoea & & 0.00 & 0.55 & 5.98 & 2.44 & 9.95 \\
\hline Amorphous & & 0.33 & 0.42 & 3.92 & 1.51 & 6.51 \\
\hline Arthropod parts & & 0.41 & 0.66 & 3.52 & 1.11 & 5.85 \\
\hline Amphipoda & & 0.45 & 0.30 & 3.50 & 1.28 & 5.82 \\
\hline Arachnidae & & 0.12 & 0.39 & 3.50 & 1.81 & 5.82 \\
\hline Hemiptera & & 0.41 & 0.59 & 3.44 & 1.23 & 5.73 \\
\hline Hymenoptera & & 0.10 & 0.30 & 3.18 & 1.28 & 5.29 \\
\hline Collembola & & 0.12 & 0.20 & 2.66 & 0.97 & 4.43 \\
\hline Unidentified arthropod & & 0.12 & 0.17 & 2.35 & 0.87 & 3.91 \\
\hline Copepoda & & 0.16 & 0.10 & 2.25 & 0.70 & 3.75 \\
\hline Unidentified decapod & & 0.11 & 0.13 & 2.17 & 0.69 & 3.61 \\
\hline Chironomidae & & 0.00 & 0.20 & 2.10 & 1.08 & 3.50 \\
\hline Odonata & & 0.11 & 0.11 & 2.04 & 0.69 & 3.40 \\
\hline Orthoptera & & 0.09 & 0.13 & 1.93 & 0.71 & 3.21 \\
\hline \multirow[t]{3}{*}{ Diptera } & & 0.49 & 0.49 & 1.92 & 1.15 & 3.19 \\
\hline & & & & & & Total 73.95 \\
\hline & Sp vs. W & Spring & Winter & $56.67(\%)$ & & \\
\hline Arthropod parts & & 0.41 & 0.41 & 5.79 & 1.14 & 10.21 \\
\hline Amorphous & & 0.33 & 0.17 & 5.70 & 1.00 & 10.05 \\
\hline Hemiptera & & 0.41 & 0.41 & 5.61 & 1.20 & 9.89 \\
\hline Amphipoda & & 0.45 & 0.67 & 5.15 & 1.14 & 9.08 \\
\hline Diptera & & 0.49 & 0.59 & 4.42 & 1.24 & 7.80 \\
\hline Collembola & & 0.12 & 0.20 & 4.08 & 0.82 & 7.20 \\
\hline Copepoda & & 0.16 & 0.00 & 2.49 & 0.57 & 4.40 \\
\hline Arachnidae & & 0.12 & 0.04 & 2.25 & 0.67 & 3.97 \\
\hline Eggs & & 0.11 & 0.04 & 2.19 & 0.53 & 3.87 \\
\hline \multirow[t]{3}{*}{ Unidentified decapod } & & 0.11 & 0.05 & 2.19 & 0.53 & 3.86 \\
\hline & & & & & & Total 70.34 \\
\hline & Su vs. W & Summer & Winter & $61.20(\%)$ & & \\
\hline Crab zoea & & 0.55 & 0.00 & 6.53 & 2.39 & 10.67 \\
\hline Amphipoda & & 0.30 & 0.67 & 5.19 & 1.41 & 8.47 \\
\hline Amorphous & & 0.42 & 0.17 & 4.45 & 1.65 & 7.27 \\
\hline Arachnidae & & 0.39 & 0.04 & 4.32 & 2.14 & 7.05 \\
\hline Arthropod parts & & 0.66 & 0.41 & 4.00 & 1.04 & 6.54 \\
\hline Hemiptera & & 0.59 & 0.41 & 3.77 & 1.20 & 6.16 \\
\hline Hymenoptera & & 0.30 & 0.05 & 3.25 & 1.29 & 5.31 \\
\hline Diptera & & 0.49 & 0.59 & 3.25 & 1.46 & 5.30 \\
\hline Collembola & & 0.20 & 0.20 & 3.13 & 1.02 & 5.11 \\
\hline Chironomidae & & 0.20 & 0.03 & 2.29 & 1.11 & 3.74 \\
\hline Unidentified arthropod & & 0.17 & 0.03 & 2.08 & 0.76 & 3.39 \\
\hline \multirow[t]{2}{*}{ Unidentified decapod } & & 0.13 & 0.05 & 1.92 & 0.61 & 3.13 \\
\hline & & & & & & Total 72.15 \\
\hline
\end{tabular}

\section{DISCUSSION}

Although few studies have illustrated or statistically examined sexually dimorphic characters for fundulids, our findings agree with general descriptions in this family (Newman 1907, Fowler 1916, Byrne 1978, Thompson 1999). Pigmented characters like vertical bars and heavily pigmented dorsal coloration were more reliable for identifying males than was the pres- ence of lemon-yellow colored anal fins. Our observation that colored anal fins were not reliable year-round for distinguishing males from females is attributed to a fading of fin color during preservation and/or collecting individuals either entering or ending reproductive activity. Thompson (1999) indicated that some male Fundulus jenkinsi develop a lemon-yellow color to their anal fin that females never develop, as well as vertical bars and a small exposed genital papilla. Sim- 

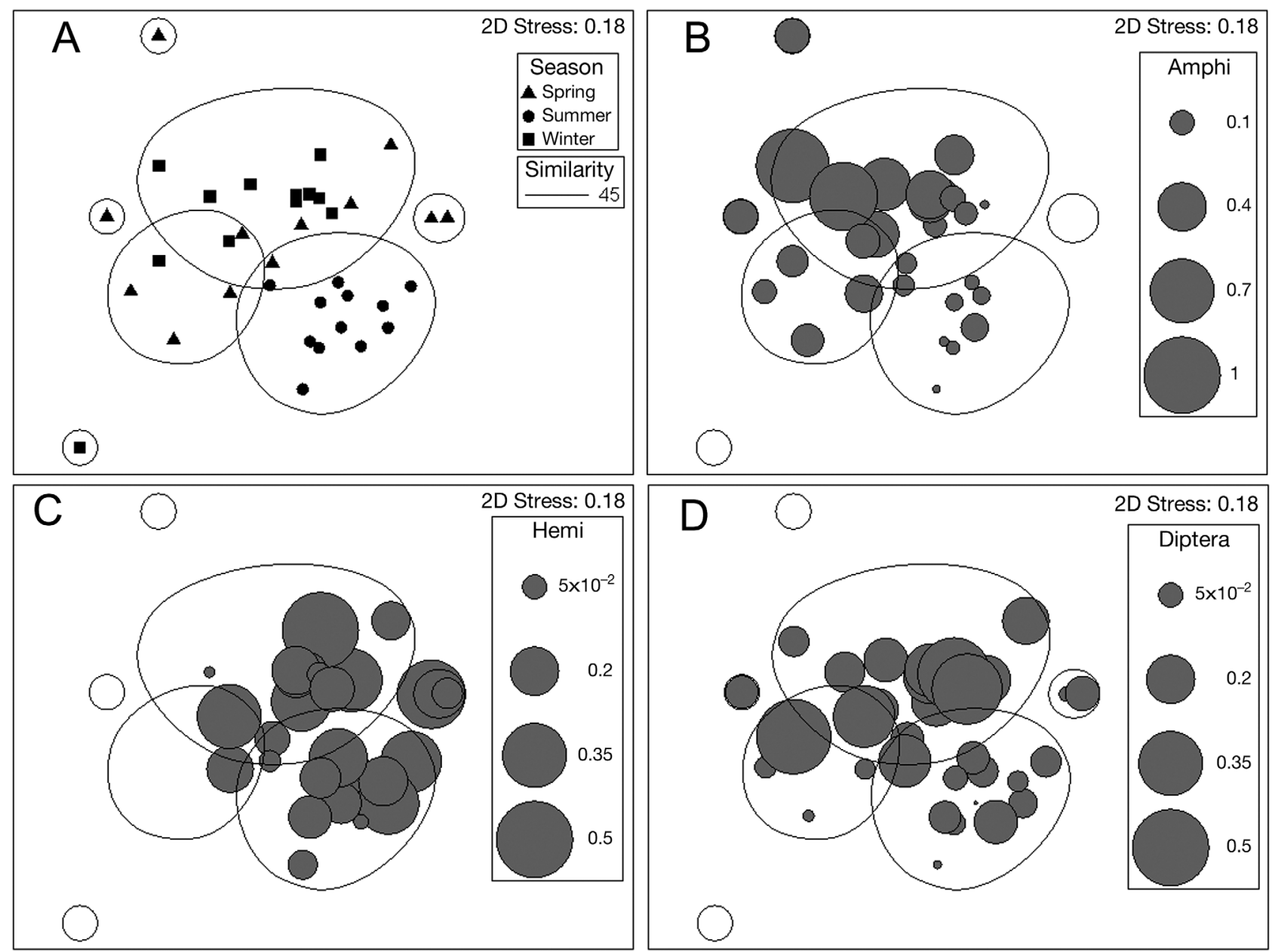

Fig. 4. Multi-dimensional spacing (MDS) and 2D plots showing seasonal patterns of Fundulus jenkinsi diet. (A) Seasonal pattern of prey taxa consumed, grouped by $45 \%$ similarity (solid line) based on cluster analysis; (B) Amphi: Amphipoda; (C) Hemi: Hemiptera; (D) Diptera; (E) Arachn: Arachnidae; (F) Hymen: Hymenoptera; (G) Copepod: Copepoda; (H) Zoea: crab zoea. All values were 4 th-root transformed prior to analysis

ilarly, male F. luciae belly, pelvic, and anal fins were yellowish-orange, coupled with intense vertical bars and the dorsal fin ocellus that developed in March through August with increased reproductive activity (Byrne 1978). However, F. jenkinsi is a batch spawner, and we may have collected a number of individuals after spawning at the end of spring tide events (Greeley \& MacGregor 1983), which may help explain why colored anal fins were not useful. Males in this study were observed with vertical bars and dorsal coloration from May through August; however, males collected in August (62\% of all spawning males) may have stopped producing anal coloration as their reproductive season was ending. Byrne (1978) noted that a change in coloration signaled sexual maturity for adults entering a reproductive season, but available literature in fundulids does not address when these fish begin to lose fin coloration. Morphological structural characters were useful to correctly distinguish mature males from females. The longer posterior anal ray in $F$. jenkinsi males agreed with descriptions of $F$. majalis males often having larger fins than females (Fowler 1916). Newman (1907) indicated that elongated anal fins in spawning males of $F$. heteroclitus and F. majalis are used to clasp responsive females during spawning. Females instead have an anal sheath which is speculated to aid in oocyte positioning (Fowler 1916, Thompson 1999) and was present in most mature females we examined. Thus, morphological characteristics such as anal sheath, genital papilla, and length of the anal ray are better characteristics for distinguishing male from female $F$. jenkinsi, although pigmentation enhances differentiation between genders during the reproductive season. 

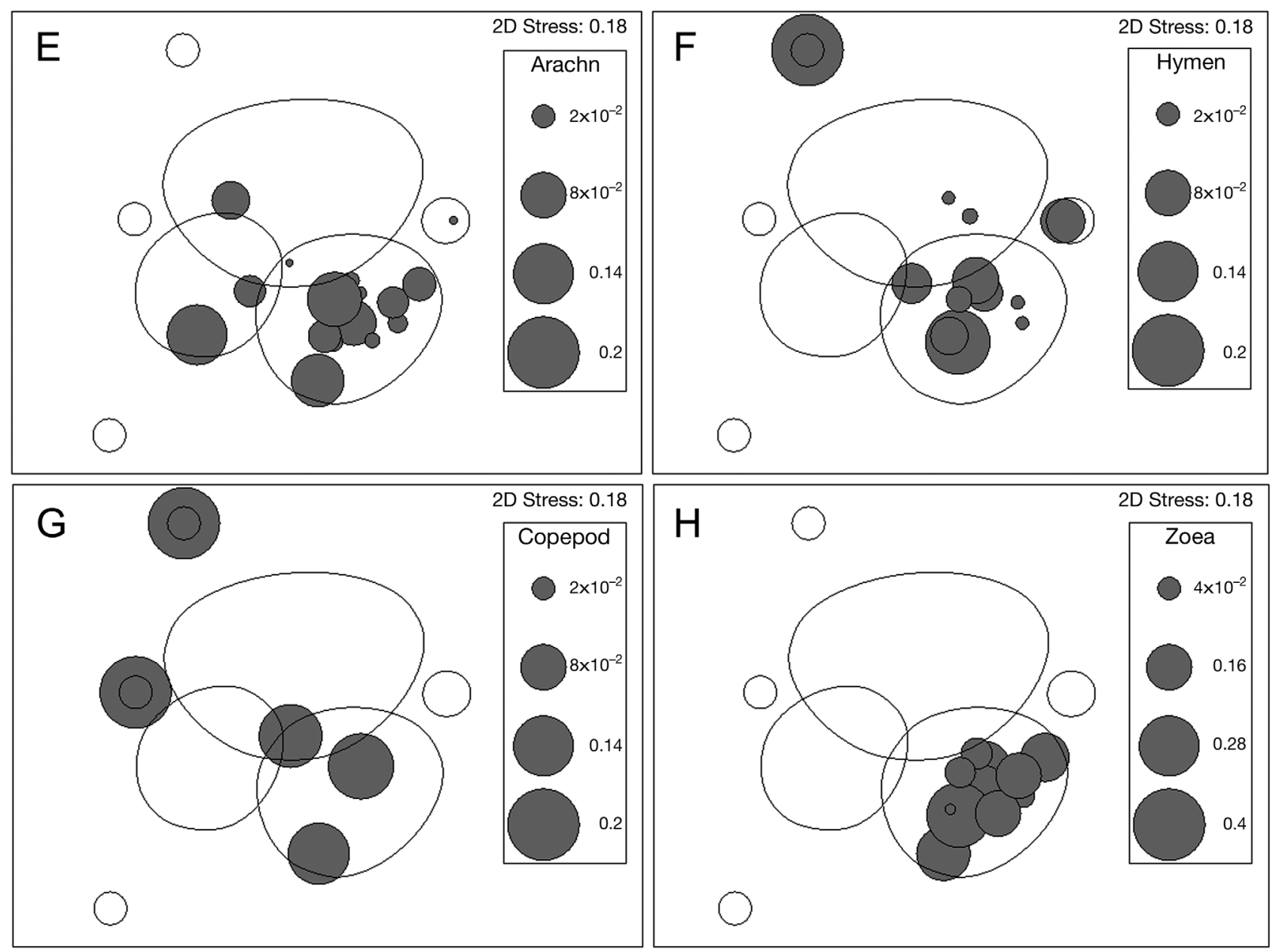

Fig. 4 (continued)

Knowledge of the season- and size-related timing of reproduction in fundulids is also important. In our study, Fundulus jenkinsi ovary phase and oocyte stage distributions showed a seasonal pattern characteristic of many fundulids. Samples with the highest percentage of early developing ovaries were seen in winter and progressively decreased toward the summer, while late developing phase ovaries steadily increased with warmer months. Greeley \& MacGregor (1983) showed a similar seasonal cycle of female gonadal recrudescence in $F$. grandis starting in January and February. They also showed that F. grandis had the highest number of mature ovaries and oocytes (diameter $>1.6 \mathrm{~mm}$ ) from March through August, which was similar to F. jenkinsi in our study (mature oocyte diameter $>1.3 \mathrm{~mm}$ ), indicative of actively spawning fish. Few actively spawning females were found in summer, since most summer collections occurred at the end of the spawning season when ovaries no longer contained oocytes $>1.3 \mathrm{~mm}$ diameter. Greeley \& MacGre- gor (1983) indicated that small ovaries and oocytes were frequent with neap tides and that large ovaries and oocytes were present in females during spring tides, suggesting that spawning activity may be associated with large inundations of marsh habitat. It is not surprising that we did not find many actively spawning fish with the largest oocyte sizes, because we sampled on multiple tidal cycles over the course of this study. Indeed, during the peak spawning period in spring, only $30 \%$ of the adult $F$. jenkinsi were captured during spring tides. This explains the low percentage of spawning-capable fish in spring (Fig. 2A), as fish captured during neap tides would be more common in the early and late development phases. Further, ovarian phase and oocyte stage were not only seasonally influenced but also size dependent, and only immature phase ovaries and cortical alveolar oocytes were found in fish $<20 \mathrm{~mm}$ SL. Similarly, F. luciae $<20 \mathrm{~mm}$ SL were juveniles and typically did not have either developed ovaries or oocytes (Byrne 1978, Kneib 1978). Finally, as 


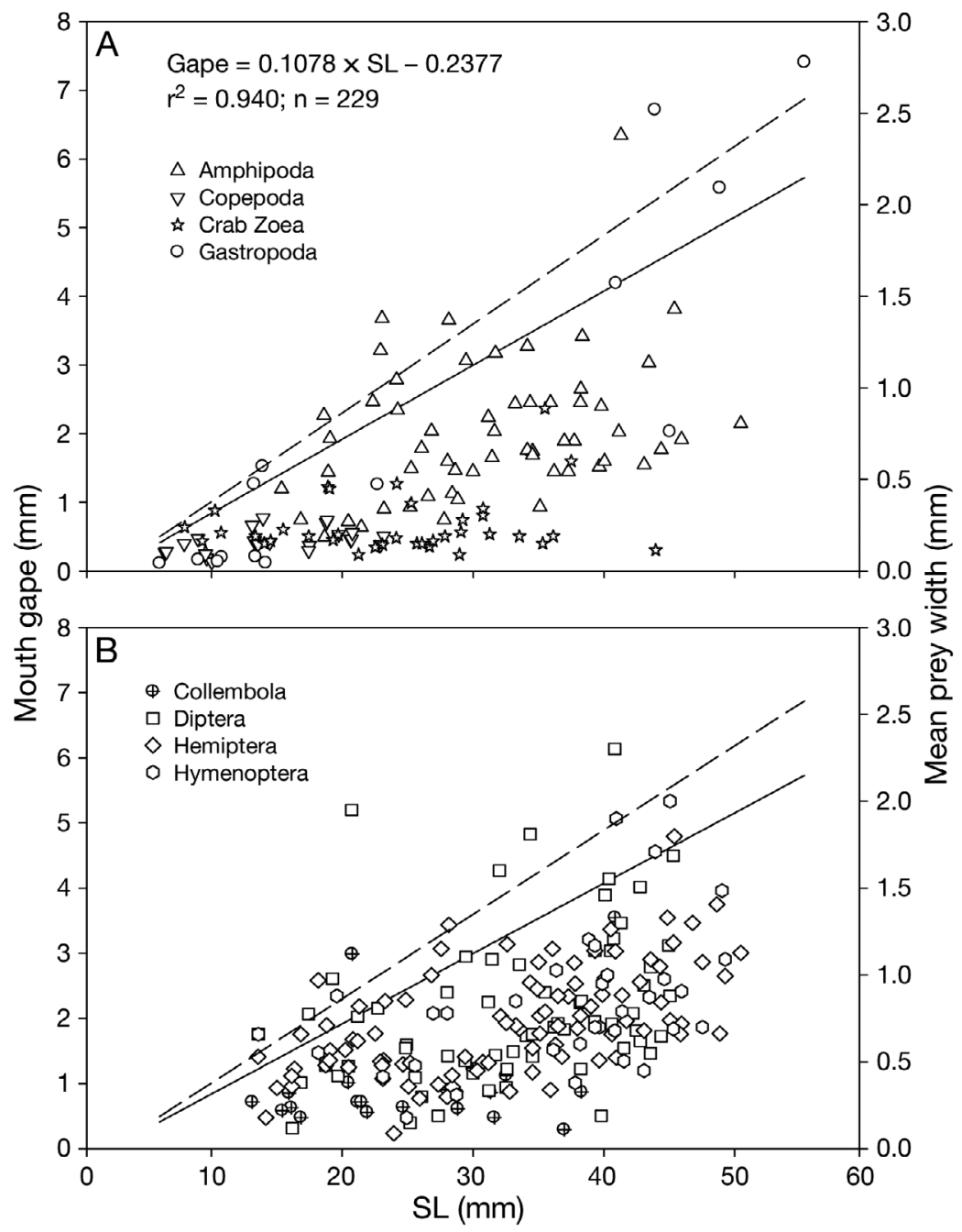

Fig. 5. Fundulus jenkinsi. Regression plot of mouth gape $(\mathrm{mm})$ and mean prey width (mm) of (A) 4 aquatic prey taxa and (B) 4 terrestrial prey taxa consumed versus fish standard length $(\mathrm{SL}, \mathrm{mm})$. Solid line: regression relationship between SL and mouth gape for the subset of fish used in the diet analysis, dashed line: $20 \%$ enlargement of potential prey body depth due to compression of prey during consumption (Peterson \& VanderKooy 1996) and relatively long-sloping dorsal shape, F. jenkinsi likely ride flood tides well into the mid- and high marsh of infrequently flooded marshes (Stout 1984, Kneib 1997). This is illustrated by the suite of terrestrial prey such as the variety of insects and aquatic prey like crab zoea, copepods, amphipods, and gastropods (off plant stems) that are similar to prey consumed by other fundulids, although prey of other fundulids also come from benthic microhabitats. For example, Rozas \& LaSalle (1990) demonstrated that $F$. grandis had diets composed mainly of aquatic arthropods but fed consistently on smaller amounts of terrestrial insects. F. confluentus and $F$. luciae are of similar body size as $F$. jenkinsi, and utilize the high marsh for consumption of terrestrial insects (Harrington \& Harrington 1961, Odum \& Heald 1972, Kneib 1978). Kneib (1978) indicated that although F. luciae does share common small crustacean prey with $F$. heteroclitus during colder months in the high marsh of the Atlantic coast, F. luciae relies more heavily on insects during summer months; a similar seasonal pattern is reflected in the diet of $F$. jenkinsi.

Fundulus jenkinsi is an opportunistic predator (aquatic and terrestrial prey) with a seasonally varied diet. The ANOSIM and MVDISP results indicated similar diets between winter and spring, with a high diversity of prey consumed. Summer diets were the most distinct of the 3 seasons and were the least diverse, as illustrated by the closeness of the diets in MDS space. Further,

ovaries develop into the actively spawning phase and contain oocytes undergoing oocyte maturation, sexually mature female fish weight is expected to be higher than that of mature males. However, our results showed that male and female $F$. jenkinsi WW did not differ when adjusted for SL, which was similarly reported for F. luciae (Kneib 1978).

Strong linkages between foraging and salt marsh habitat use, termed 'trophic relay', have been documented for a variety of nekton (Kneib 1997, 2000). Fundulus jenkinsi, captured at the mid-marsh edge or in small intertidal creeks leaving the high marsh on ebb tides, consumed both terrestrial (mid- and high marsh) and aquatic organisms in marshes in the northern GOM. Given their small body size, upturned mouths,
SIMPER showed that crab zoea contributed the most to dissimilarities between spring and summer and winter and summer diets, while arthropod parts, Hemiptera, Amphipoda, Diptera, and Collembola contributed the most to dissimilarity between spring and winter. In fact, the 2D bubbles superimposed on the MDS plot illustrated that crab zoea were only present in summer, and terrestrial insects like Hemiptera and Diptera were present in all seasons. Consumption of crab zoea only during the summer was probably a result of large quantities of this prey as they can be released from mid-June through September (Hovel \& Morgan 1997).

Terrestrial insects were seasonally variable in Fundulus jenkinsi diets. Both dipterans and hemipterans emerge from late May through September (Merritt \& 
Table 4. Common prey in Fundulus jenkinsi diets showing occurrence across fish size classes with minimum (min) and maximum (max) prey widths. SL: standard length

\begin{tabular}{|c|c|c|c|}
\hline \multirow{2}{*}{ Prey } & \multirow{2}{*}{$\begin{array}{l}\text { Fish size } \\
(\mathrm{SL}, \mathrm{mm})\end{array}$} & \multicolumn{2}{|c|}{ Prey size $(\mathrm{mm})$} \\
\hline & & Min & Max \\
\hline \multicolumn{4}{|l|}{ Aquatic } \\
\hline Amphipoda & $9.55-50.45$ & 0.09 & 2.38 \\
\hline Gastropoda & $\begin{array}{r}6.06-22.72 \\
40.94-55.32\end{array}$ & 0.04 & 2.78 \\
\hline Copepoda & $6.46-23.17$ & 0.05 & 0.29 \\
\hline Crab zoea & $7.96-43.95$ & 0.09 & 0.89 \\
\hline \multicolumn{4}{|l|}{ Terrestrial } \\
\hline Collembola & $13.12-40.85$ & 0.11 & 1.33 \\
\hline Diptera & $13.59-45.30$ & 0.12 & 2.30 \\
\hline Hemiptera & $13.57-50.45$ & 0.09 & 1.80 \\
\hline Hymenoptera & $18.17-49.27$ & 0.18 & 2.00 \\
\hline
\end{tabular}

Cummins 1996), yet they were present in diets across all seasons. However, hymenopterans, which hatch from May to June (Merritt \& Cummins 1996), were only recorded in the diets of $F$. jenkinsi in summer. Examination of seasonal diets suggested that insects were most abundant during the summer, with smaller crustaceans and gastropods making up diets in the spring and winter (Tables S1 to S3 in the supplement). Kneib (1978) reported similar seasonal dietary shifts in F. luciae, with diet consisting mainly of small crustaceans and mollusks during the colder months (February to April) but shifting to detrital material and insects in the warmer months.

Fundulus jenkinsi diets have both spatial and time of day components of variability pooled into our analysis. This clearly added variability to the diet, as prey availability varies by geographic area sampled, habitat type, tidal height, elevation (Byrne 1978, Rozas \& LaSalle 1990, Moy \& Levin 1991, Allen et al. 1994), and possibly time of day. For example, we collected many F. jenkinsi in Weeks Bay National Estuarine Research Reserve (NERR), which is a more freshwater-dominated marsh (Miller-Way et al. 1996). Freshwaterinfluenced marshes have adjacent upland areas (treelined borders) which provide a suite of terrestrial prey items during flooding events (Stout 1984). In contrast, the Grand Bay NERR is mainly marine influenced (Walters \& Dillon 2007), and fewer F. jenkinsi were collected there. This spatial variation in habitat may have influenced the overall prey spectrum available to and consumed by F. jenkinsi. A similar pattern was noted by Nemerson \& Able (2004) for white perch Morone americana and Atlantic croaker Micropogonias undulatus, which consumed insects (up to $29.8 \%$ and $15.1 \%$, respectively) in Delaware Bay marsh creeks, but the diets varied based on whether the marsh was in a low salinity or marine-dominated subsystem within the larger ecosystem.
These differences in the marsh environment as reflected in prey availability, coupled with wide spatial sampling, contributed to the variability in Fundulus jenkinsi diet. Furthermore, we only sampled during the day in this study, which may have influenced the results. Typically, during spring and summer months, the marsh is inundated during the day, while it is mainly flooded at night during the winter. However, Weisberg et al. (1981) found that although nocturnal feeding activity by $F$. heteroclitus did occur, it was significantly less than daytime flood tidal feeding. The authors reasoned that $F$. heteroclitus is a visual feeder and therefore daytime sampling of marshes would be more representative of fundulid diet (Weisberg et al. 1981).

In addition to seasonal and spatial prey variability, mouth gape increased with increasing fish size in Fundulus jenkinsi regardless of gender. This relationship suggests that large $F$. jenkinsi have the morphology to consume larger and more energetically beneficial prey items as they grow. Werner \& Gilliam (1984) indicated that fish select larger prey that offer the most energetic gain with the least energetic cost of capture and handling. Fish $<20 \mathrm{~mm}$ SL had aquatic prey comprised of small-bodied organisms (copepods and gastropods) that shifted toward large (amphipods) or abundant (crab zoea) prey in fish $>20 \mathrm{~mm}$ SL. Interestingly, crab zoea, found only in summer diets, were consumed across many size classes, suggesting that these opportunistic fish were consuming prey encountered in the water column as long as it would fit within the predator gape limit. Mean prey width, adjusted for the $20 \%$ increase, ranged from 0.05 to $3.34 \mathrm{~mm}$, which suggested that a $55 \mathrm{~mm}$ SL fish can consume prey that are 67 times greater width, on average, than a $6 \mathrm{~mm}$ SL fish. This scale of variability in the size of prey consumed was also shown for F. luciae, as their diet ranged from detritus and diatoms to dipterans and copepods as fish grew larger (Byrne 1978, Kneib 1978).

Overall, we have shown that morphological characters were more consistent than pigmented characters in distinguishing males from females, and we have provided the first illustrations of these important morphological characters for the family. We found that spawning initiated in spring and early summer months, and that fish $<20 \mathrm{~mm}$ SL were juveniles. We have also shown that Fundulus jenkinsi is a gape-limited forager, that prey body width shifted to larger sizes as F. jenkinsi grew, and, like F. luciae, this species makes use of high tide events to forage on terrestrial and aquatic prey. Clearly, the use of mid- and high marsh habitat by F. jenkinsi across its range (Lopez et al. 2010), coupled with reproductive activities and feeding upon terrestrial and aquatic sources of energy, point to the importance of marsh access for reproduction and to the trophodynamics of this rare species. 
Alteration of the salt marsh edge by plot-scale destruction (e.g. bulkheads and rip-rap), which leads to large-scale cumulative impacts (Peterson \& Lowe 2009) and fishery resource reduction in estuaries (Jordan et al. 2008), can interrupt, modify, and ultimately eliminate access to mid- and high marsh for reproduction and foraging of all species that link subtidal and intertidal habitats. Recent modeling studies have shown that hard structures in fringing salt marsh change marsh-shoreline relationships considerably, such that function is modified; this is rarely considered in management scenarios (Mattheus et al. 2010). Fundulus jenkinsi, as well as other species, use high spring tides to enhance spawning and foraging activities, and thus preservation of 'dendritic' tidal creeks that provide high marsh access is an important consideration when developing a comprehensive conservation plan for the species and its habitat.

Acknowledgements. We thank J. Walker and G. Grammer of the Grand Bay NERR for assistance with field sampling and QA/QC procedures. Numerous people assisted with logistics and/or field work or use of equipment, and their help is very much appreciated: C. Ellinwood, M. Lowe, J.M. Havrylkoff, P. Grammer, M. Andres, D. Ruple, M. Woodrey, R. DeMay, S. Phipps, L. Edminston, J. Wanat, G. Thomassie, R. Neil, and C. Rakocinski. N.J. Brown-Peterson reviewed a draft of this paper. We thank the NOAA Office of Protected Fisheries, Proactive Species Conservation Grant Program, for providing funding for this project. State sampling permits from Louisiana, Mississippi, Alabama, and Florida were in place prior to collecting. This research was authorized at the University of Southern Mississippi by the Institutional Anima Care and Use Committee under No. 07011101.

\section{LITERATURE CITED}

Abele LG, Kim W (1986) An illustrated guide to the marine decapod crustaceans of Florida. Tech Ser 8. State of Florida, Department of Environmental Regulation, Tallahassee, FL

Allen EA, Fell PE, Peck A, Gieg JA, Guthke CR, Newkirk MD (1994) Gut contents of common mummichogs, Fundulus heteroclitus L., in a restored impounded marsh and in natural reference marshes. Estuaries 17:462-471

Babkin BP, Bowie DJ (1928) The digestive system and its function in Fundulus heteroclitus. Biol Bull 54:254-277

Boschung HT Jr, Mayden RL (2004) Fishes of Alabama. Smithsonian Books, Washington, DC

Breder CM Jr (1960) Design of a fry trap. Zoologica 45:155-160

Brown-Peterson NJ, Lowerre-Barbieri SK, Macewicz, BJ Saborido-Rey F, Tomkiewicz J, Wyanski DM (2007) An improved and simplified terminology for reproductive classification in fishes. Available at: http://hdl.handle.net/ $10261 / 11844$

$>$ Byrne DM (1978) Life history of the spotfin killifish, Fundulus luciae (Pisces: Cyprinodontidae), in Fox Creek Marsh, Virginia. Estuaries 1:211-227

> Clarke KR (1993) Non-parametric multivariate analyses of changes in community structure. Aust J Ecol 18:117-143

Clarke KR, Gorley RN (2006) PRIMER v6. PRIMER-E Ltd. Plymouth Marine Laboratory, Plymouth
Field A (2005) Discovering statistics using SPSS, 2nd edn. Sage Publications, London

Foster NR (1967) Comparative studies on the biology of killifishes (Pisces: Cyprinodontidae). PhD dissertation, Cornell University, Ithaca, NY

Fowler HW (1916) Some features of ornamentation in the killifishes or toothed minnows. Am Nat 50:743-750

Gilbert CR, Relyea K (1992) Saltmarsh topminnow, Fundulus jenkinsi. In: Gilbert CR (ed) Rare and endangered biota of Florida, Vol II. University Press of Florida, Gainsville, FL, p 68-72

Granier BG (1998) Spawning the marsh killifish, Fundulus confluentus. Am Curr 1998:12

Greeley MS Jr (1984) Spawning by Fundulus pulvereus and Adinia xenica along the Alabama Gulf Coast is associated with the semilunar tidal cycles. Copeia 1984:797-800

Greeley MS Jr, MacGregor R III (1983) Annual and semilunar reproductive cycles of the gulf killifish, Fundulus grandis, on the Alabama Gulf coast. Copeia 1983:711-718

Greeley MS Jr, Marion KR, MacGregor R III (1986) Semilunar spawning cycles of Fundulus similis. Environ Biol Fishes 17:125-131

Grier HJ, Uribe-Aranzábel MC, Patiño R (2009) The ovary, folliculogenesis, and oogenesis in teleosts. In: Jamieson BGM (ed) Reproductive biology and phylogeny of fishes (agnathans and bony fishes), Vol 8A. Science Publishers, Enfield, NH, p 25-84

Hardy JD Jr (1980a) Fundulus confluentus Goode and Bean, marsh killifish. In: Lee DS, Gilbert CR, Hocutt $\mathrm{CH}_{\text {, Jenkins }}$ RE, McAllister DE, Stauffer JR Jr (eds) Atlas of North American freshwater fishes. North Carolina State Museum of Natural History, Raleigh, NC, p 512

Hardy JD Jr (1980b) Fundulus pulvereus (Evermann), bayou killifish. In: Lee DS, Gilbert CR, Hocutt $\mathrm{CH}$, Jenkins RE, McAllister DE, Stauffer JR Jr (eds) Atlas of North American freshwater fishes. North Carolina State Museum of Natural History, Raleigh, NC, p 525

> Harrington RW, Haeger JS (1958) Prolonged natural deferment of hatching in killifish. Science 128:1511

> Harrington RW, Harrington ES (1961) Food selection among fishes invading a high subtropical salt marsh: from onset of flooding through the progress of a mosquito brood. Ecology 42:646-666

Harrington RW, Harrington ES (1972) Food of female marsh killifish, Fundulus confluentus Goode and Bean, in Florida. Am Midl Nat 87:492-502

Heard RW (1982) Guide to common tidal marsh invertebrates of the northeastern Gulf of Mexico. Mississippi-Alabama Sea Grant Consortium, MASGC-79-004, Ocean Springs, MS

Heard RW, Price WW, Knott DM, King RA, Allen DM (2006) A taxonomic guide to the mysids of the South Atlantic Bight. NOAA Professional Paper NMFS 4

Hovel KA, Morgan SG (1997) Planktivory as a selective force for reproductive synchrony and larval migration. Mar Ecol Prog Ser 157:79-95

Hyslop EH (1980) Stomach contents analysis: a review of methods and their application. J Fish Biol 17:411-429

Jordan SJ, Smith LM, Nestlerode JA (2008) Cumulative effects of coastal habitat alterations on fishery resources: toward prediction at regional scales. Ecol Soc 14:16

Kilby JD (1955) The fishes of two Gulf coastal marsh areas in Florida. Tulane Stud Zool 2:175-247

- Kneib RT (1978) Habitat, diet, reproduction, and growth of the spotfin killifish, Fundulus luciae, from a North Carolina salt marsh. Copeia 1978:164-168

Kneib RT (1986) The role of Fundulus heteroclitus in salt marsh dynamics. Am Zool 26:259-269 
Kneib RT (1997) The role of tidal marshes in the ecology of estuarine nekton. Oceanogr Mar Biol Annu Rev 35: $163-220$

Kneib RT (2000) Saltmarsh ecoscapes and production transfers by estuarine nekton in the southeastern U.S. In: Weinstein MP, Kreeger DA (eds) Concepts and controversies in tidal marsh ecology. Kluwer Academic, Dordrecht, p 267-292

Lawrence JM (1958) Estimated sizes of various forage fishes largemouth bass can swallow. Proc Annu Conf SE Assoc Game Fish Comm 11:220-225

Lefeuvre JC, Laffaille P, Feunteum E (1999) Do fish communities function as biotic vectors of organic matter between salt marshes and marine coastal waters? Aquat Ecol 33: 293-299

Lopez JD, Peterson MS, Walker J, Grammer GL, Woodrey MS (2010) Distribution, abundance, and habitat characterization of the saltmarsh topminnow, Fundulus jenkinsi (Everman [sic] 1892). Estuar Coasts doi:10.1007/s12237-010 9266-5

Mattheus CR, Rodriguez AB, McKee BA, Currin C (2010) Impact of land-use change and hard structures on the evolution of fringing marsh shorelines. Estuar Coast Shelf Sci 88:365-376

Merritt RW, Cummins KW (1996) An introduction to the aquatic insects of North America, 3rd edn. Kendall/Hunt Publishing Co., Dubuque, IA

Miller-Way T, Dardeau M, Crozier G (1996) Weeks Bay National Estuarine Research Reserve: an estuarine profile and bibliography. Dauphin Island Lab Tech Rep 96-01

Moy LD, Levin LA (1991) Are Spartina marshes a replaceable resource? A functional approach to evaluation of marsh creation efforts. Estuaries 14:1-16

National Oceanic and Atmopheric Administration (NOAA) (2009) Proactive conservation program: species of concern. NOAA Fisheries, Office of Protected Resources. www.nmfs.noaa.gov/pr/species/concern

Nemerson DM, Able KW (2004) Spatial patterns in diet and distribution of juveniles of four species in Delaware Bay marsh creeks: factors influencing fish abundance. Mar Ecol Prog Ser 276:249-262

> Newman HH (1907) Spawning behavior and sexual dimorphism in Fundulus heteroclitus and allied fish. Biol Bull $12: 314-348$

- Newman HH (1909) Contact organs in the killifishes of Woods Hole. Biol Bull 17:170-180

> Nordlie FG (2006) Physicochemical environments and tolerances of cyprinodontoid fishes found in estuaries and salt marshes of eastern North America. Rev Fish Biol Fish 16 51-106

Odum WE, Heald EJ (1972) Trophic analysis of an estuarine mangrove community. Bull Mar Sci 22:671-738

Peterson MS, Lopez JD (2008) Fundulus jenkinsi, saltmarsh topminnow: conservation planning and implementationYears 1 and 2. Final report submitted to Grand Bay National Estuarine Research Reserve, Moss Point, MS

Peterson MS, Lowe MR (2009) Implications of cumulative impacts to estuarine and marine habitat quality for fish and invertebrate resources. Rev Fish Sci 17:505-523

Peterson MS, VanderKooy SJ (1996) Preservation-induced changes in morphometrics of fishes: influence on prey size-choice in juvenile walleye, Stizostedion vitreum (Mitchill). Ecol Freshw Fish 5:133-139

Peterson MS, Fulling GL, Woodley CM (2003) Status and

Editorial responsibility: Cornelius Hammer,

Rostock, Germany habitat characteristics of the saltmarsh topminnow, Fundulus jenkinsi (Evermann), in eastern Mississippi and western Alabama coastal bayous. Gulf Caribb Res 15: 51-59

Rakocinski CF, Zapfe GA (2005) Macrobenthic process indicators of estuarine condition. In: Bortone $\mathrm{S}$ (ed) Estuarine indicators. CRC Press, Boca Raton, FL, p 315-331

Reid GK Jr (1954) An ecological study of the Gulf of Mexico fishes, in the vicinity of Cedar Key, Florida. Bull Mar Sci Gulf Caribb 4:1-94

Relyea KG (1965) Taxonomic studies of the cyprinodont fishes, Fundulus confluentus Goode and Bean, and Fundulus pulvereus (Evermann). Florida State University, Tallahassee, FL

Ross ST (2001) Inland fishes of Mississippi. University of Mississippi Press, Jackson, MS

Rountree RA, Able KW (2007) Spatial and temporal habitat use patterns for salt marsh nekton: implications for ecological functions. Aquat Ecol 41:25-45

Rozas LP, LaSalle MW (1990) A comparison of the diets of gulf killifish, Fundulus grandis Baird and Girard, entering and leaving a Mississippi brackish marsh. Estuaries 13: 332-336

Schiemer F, Zalewski M, Thorpe JE (1995) Land/inland water ecotones: intermediate habitats critical for conservation and management. Hydrobiologia 303:259-264

Stout JP (1984) The ecology of irregularly flooded salt marshes of the northeastern Gulf of Mexico: a community profile. US Department of the Interior, Fish and Wildlife Service, Biol Rep 85, Washington, DC

Swingle HA, Bland DG (1974) A study of the fishes of the coastal watercourses of Alabama. Ala Mar Res Bull 10: $17-102$

Taylor CA, Burr BM (1997) Reproductive biology of the northern starhead topminnow, Fundulus dispar (Osteichthyes: Fundulidae), with a review of data for freshwater members of the genus. Am Midl Nat 137:151-164

Thompson BA (1980) Fundulus jenkinsi (Evermann), salt-

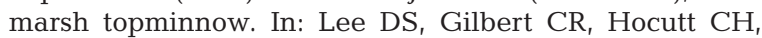
Jenkins RE, McAllister DE, Stauffer JR Jr (eds) Atlas of North American freshwater fishes. North Carolina State Museum of Natural History, Raleigh, NC, p 518

Thompson BA (1999) An evaluation of the saltmarsh topminnow, Fundulus jenkinsi. Final Report to the US Department of Commerce, National Marine Fisheries Service, SE Regional Office, St. Petersburg, FL

Timmerman CM, Annett CA, Bailey CF (2000) Determination of factors limiting prey size swallowed by larval and small juvenile largemouth bass. Trans Am Fish Soc 129:618-622

Walters SC, Dillon KS (2007) Water quality. In: Peterson MS, Grammer G, Woodrey MS (eds) Grand Bay National Estuarine Research Reserve: an ecological characterization. Moss Point, MS, p 79-96

Weisberg SB, Whalen R, Lotrich VA (1981) Tidal and diurnal influence on food consumption of a salt marsh killifish Fundulus heteroclitus. Mar Biol 61:243-246

Werner EE, Gilliam JF (1984) The ontogenetic niche and species interactions in size-structured populations. Annu Rev Ecol Syst 15:393-425

Wieland RG (2007) Habitat types and associated ecological communities of the Grand Bay National Estuarine Research Reserve. In: Peterson MS, Grammer G, Woodrey MS (eds) Grand Bay National Estuarine Research Reserve: an ecological characterization. Moss Point, MS, p 104-147

Submitted: April 9, 2010; Accepted: May 31, 2010

Proofs received from author(s): July 12, 2010 